ISSN (Print) : 1412-7601

ISSN (Online) : 2654-8712

Volume 4, No.2 September 2018

EKONOBIS

http://www.ekonobis.unram.ac.id

\title{
Analisis Penentuan Desa Pusat Pertumbuhan Di Kecamatan Lembar Kabupaten Lombok Barat
}

\author{
Emi Salmah, Sahri, Endang Astuti
}

Universitas Mataram

\begin{tabular}{l|l}
\hline A R T I C LE INFO & Received : 15 Juni 2018; Accepted: 21 Juli 2018; Published: September 2018 \\
\hline Keywords: & ABSTRACT : This study aims to: a). Identify the availability of facilities and
\end{tabular}

Center for growth and $\quad$ infrastructure for each village in Sheet District, b). Determine suitable villages to be

Lembar sub district. $\quad$ developed as the Growth Center Village in Lembar District. The type of research used is descriptive research. The results of the study show that the facilities and infrastructure in Lembar District in general are sufficiently available and have supported the establishment of the Center for Growth Village. The appropriate village to be developed as a Growth Center Village is Kembar Bridge Village because the weight obtained from 7 (seven) DPP determinant variables is 73, which means Twin Bridge Village. have facilities and infrastructure and have the potential to support the formation of the Growth Center Village in Lembar District, West Lombok Regency. Referring to the results of the analysis and discussion in the previous chapter and referring to the results of the above research, suggestions can be made, namely the need to develop several facilities and infrastructure to further improve the function of Twin Bridge Village as a growth center for the hinterland areas such as communication facilities, education, and procurement of business entities or companies.

Kata Kunci :

Pusat pertumbuhan dan Kecamatan lembar.
ABSTRAK : Penelitian ini bertujuan untuk: a). Mengidentifikasi ketersediaan sarana dan prasarana masing - masing desa di Kecamatan Lembar, b). Menentukan desa yang sesuai untuk dikembangkan sebagai Desa Pusat Pertumbuhan di Kecamatan Lembar. Jenis penelitian yang digunakan adalah penelitian diskriptif. Hasil penelitian menunjukkan bahwa, sarana dan prasarana yang ada di Kecamatan Lembar secara umum sudah cukup tersedia dan sudah mendukung dalam pembentukan Desa Pusat Pertumbuhan. Desa yang sesuai untuk dikembangkan sebagai Desa Pusat Pertumbuhan adalah Desa Jembatan Kembar karena bobot yang diperoleh dari 7 ( tujuh ) variabel penentu DPP sebesar 73, yang artinya Desa Jembatan Kembar. memiliki sarana dan prasarana serta memiliki potensi yang mendukung terbentuknya Desa Pusat Pertumbuhan di Kecamatan Lembar Kabupaten Lombok Barat. Mengacu pada hasil analisis dan pembahasan pada bab sebelumnya serta mengacu pada hasil penelitian di atas, maka dapat diajukan saran - saran yaitu perlu diadakan pembangunan beberapa sarana dan prasarana untuk lebih meningkatkan fungsi Desa Jembatan Kembar sebagai pusat pertumbuhan bagi daerah - daerah hinterlandnya seperti sarana komunikasi, pendidikan, serta pengadaan badan usaha atau perusahaan.

Corresponding Author :

Alamat : Program Studi Ekonomi Pembangunan, Fakultas Ekonomi dan Bisnis, Universitas Mataram, Jln. Majapahit No. 62 Mataram. 


\section{PENDAHULUAN}

\section{Latar Belakang}

Wilayah Republik Indonesia, secara keseluruhan kurang lebih terbagi kedalam 65.000 desa. Dilihat dari aspek demografinya sekitar 65\% dari total penduduk Indonesia bermukim di daerah pedesaan. Bahkan di pulau-pulau besar kawasan timur Indonesia seperti Sulawesi, Maluku dan Papua jumlah penduduk yang bermukim di perdesaan masih berada di atas 60 persen yang mempunyai mata pencaharian utama pada sektor pertanian dalam arti luas, meliputi sub-sub sektor tanaman pangan, perkebunan, peternakan, perikanan, dan kehutanan.

Kabupaten Lombok Barat sebagai salah satu kabupaten di Provinsi Nusa Tenggara Barat (NTB) yang terletak dibagian selatan $P$. Lombok dengan Ibu Kotanya ada di Gerung, terdiri dari 15 Kecamatan dan 125 Desa. Salah satu kecamatannya adalah Kecamatan Lembar yang memiliki pelabuhan laut, sebagai pintu masuk $P$. Lombok liwat laut.

Kecamatan Lembar dalam melaksanakan pembangunan menghadapi hambatan dan kendala karena kondisi desadesa di kecamatan ini bervariasi atau berbeda-beda satu sama lainnya misalnya ada desa yang sangat potensial, dan desa yang penduduknya kurang, ketersediaan infrastrukturnya kurang memadai, dan karakteristik lainnya

Oleh karena itu, untuk dapat membentuk suatu sistem pedesaan yang terpadu perlu ditetapkan Desa Pusat Pertumbuhan (DPP) untuk menunjang pertumbuhan desa dan perekonomian yang saling menguntungkan. Sejalan dengan hal tersebut maka peranan sarana dan prasarana sangat dibutuhkan.

Jika konsep Desa Pusat Pertumbuhan tidak diterapkan, kemungkinanakan sangat berdampak negatif terhadap kehidupan sosial dan ekonomi bagi masyarakat di Kecamatan Lembar. Dengan mempertimbangkan upaya tersebut, maka perlu diadakan suatu penelitian mengenai "Analisis Penentuan Desa Pusat Pertumbuhan di Kecamatan Lembar Kabupaten Lombok Barat ".

\section{Rumusan Masalah}

Sesuai dengan latar belakang yang telah dijelaskan sebelumnya, dapat dirumuskan permasalah sebagai berikut :

1. Bagaimana ketersediaan sarana dan prasarana masing - masing desa di Kecamatan Lembar

2. Desa manakah yang sesuai untuk dikembangkan sebagai Desa Pusat Pertumbuhan di Kecamatan Lembar

\section{Tujuan dan Kegunaan Penelitian}

\section{Tujuan Penelitian}

1. Mengidentifikasi ketersediaan sarana dan prasarana masing - masing desa di Kecamatan Lembar

2. Menentukan desa yang sesuai untuk dikembangkan sebagai Desa Pusat Pertumbuhan di Kecamatan Lembar.

\section{Kegunaan Penelitian}

1. Sebagai acuan bagi pemerintah setempat dalam merencanakan / mengembangkan wilayah pedesaan untuk pemerataan pertumbuhan wilayah

2. Dapat menjadi informasi dan bahan pembanding bagi para peneliti selanjutnya dalam meneliti pembangunan wilayah pedesaan.

\section{TINJAUAN PUSTAKA}

\section{Pengertian Desa}

Beberapa ahli memberikan definisin yang berbeda tentang desa. Antara lain:

1. Yayuk dan Mangku (2003)

Istilah desa berasal dari bahasa India swadesi yang berarti tempat asal, tempat tinggal, negeri asal atau tanah leluhur yang merujuk pada satu kesatuan hidup dengan kesatuan norma serta memiliki batas yang jelas.

2. Zakaria (2000)

Desa adalah sekumpulan manusia yang hidup bersama atau suatu wilayah, yang memiliki suatu organisasi pemerintahan dengan serangkaian peraturan-peraturan yang ditetapkan sendiri, serta berada di bawah pimpinan desa yang dipilih dan ditetapkan sendiri.Definisi ini, menegaskan bahwa desa sebagai satu unit kelembagaan pemerintahan mempunyai kewenangan pengelolaan wilayah perdesaan. 
Berdasarkan pengertian di atas dapat disimpulkan bahwa desa merupakan suatu kesatuan masyarakat yang dibangun berdasarkan sejarah, nilai-nilai, budaya, hukum dan keistimewaan tertentu yang diakui dalam sistem kenegaraan kesatuan Republik Indonesia yang memiliki kewenangan untuk mengatur, mengorganisir dan menetapkan kebutuhan masyarakatnya secara mandiri.

\section{Potensi Desa}

Maju mundurnya desa, sangat tergantung pada ketiga unsur di atas.Karena, unsur-unsur ini merupakan kekuasaan desa atau potensi desa.Potensi desa adalah berbagai sumber alam (fisik) dan sumber manusia (non fisik) yang tersimpan dan terdapat di suatu desa, dan diharapkan kemanfaatannya bagi kelangsungan dan perkembangan desa.

Yang termasuk ke dalam potensi desa antara lain sebagai berikut

1. Potensi fisik

Potensi fisik desa antara lain meliputi:

a. Tanah, dalam artian sumber tambang dan mineral, sumber tanaman yang merupakan sumber mata pencaharian, bahan makanan, dan tempat tinggal.

b. Air, dalam artian sumber air, kondisi dan tata airnya untuk irigasi, pertaniandan kebutuhan hidup sehari-hari.

c. Iklim, peranannya sangat penting bagi desa yang bersifat agraris.

d. Ternak, sebagai sumber tenaga, bahan makanan, dan pendapatan.

e. Manusia, sebagai sumber tenaga kerja potensial (potential man power) baik pengolah tanah dan produsen dalam bidang pertanian, maupun tenaga kerja industri di kota.

2. Potensi non fisik

Potensi non fisik desa antara lain meliputi:

a. Masyarakat desa, yang hidup berdasarkan gotong royong dan dapat merupakan suatu kekuatan berproduksi dan kekuatan membangun atas dasar kerja sama dan saling pengertian.

b. Lembaga-lembaga sosial, pendidikan, dan organisasi-organisasi sosial yang dapat memberikan bantuan sosial dan bimbingan terhadap masyarakat.

c. Aparatur atau pamong desa, untuk menjaga

ketertiban

dan

keamanandemi kelancaran jalannya pemerintahan desa. (Waluya B, 2009

\section{Teori Pusat Pertumbuhan}

Pusat pertumbuhan dapat terbentuk di suatu wilayah.Terbentuknya pusat pertumbuhan dapat terjadi secara alami atau dengan perencanaan.beberapa teori mengenai pusat pertumbuhan atau perkembangan wilayah berikut:

1. Teori Polarisasi Ekonomi

Teori polarisasi ekonomi dikemukakan oleh Gunar Myrdal. Menurut Myrdal, setiap daerah mempunyai pusat pertumbuhan yang menjadi daya tarik bagi tenaga buruh dari pinggiran. Pusat pertumbuhan tersebut juga mempunyai daya tarik terhadap tenaga terampil, modal, dan barang-barang dagangan yang menunjang pertumbuhan suatu lokasi. Demikian terusmenerus akan terjadi pertumbuhan yang makin lama makin pesat atau akan terjadi polarisasi pertumbuhan ekonomi (polarization of economic growth).

2. Teori Kutub Pertumbuhan

Konsep kutub pertumbuhan (growth pole concept) dikemukakan oleh Perroux, seorang ahli ekonomi Prancis (1950). Menurut Perroux, kutub pertumbuhan adalah pusat-pusat dalam arti keruangan yang abstrak, sebagai tempat memancarnya kekuatan-kekuatan sentrifugal dan tertariknya kekuatankekuatan sentripetal. Pembangunan tidak terjadi secara serentak, melainkan muncul di tempat-tempat tertentu dengan kecepatan dan intensitas yang berbeda. Kutub pertumbuhan bukanlah kota atau wilayah, melainkan suatu kegiatan ekonomi yang dinamis. Hubungan kekuatan ekonomi yang dinamis tercipta di dalam dan di antara sektor-sektor ekonomi.

3. Teori Pusat Pertumbuhan

Teori pusat pertumbuhan dikemukakan oleh Boudeville.Menurut Boudeville (ahli ekonomi Prancis), pusat pertumbuhan adalah sekumpulan fenomena geografis dari semua kegiatan yang ada di permukaan Bumi. Suatu kota atau wilayah kota yang mempunyai industri populasi yang kompleks, dapat dikatakan sebagai 
pusat pertumbuhan. Industri populasi merupakan industri yang mempunyai pengaruh yang besar (baik langsung maupun tidak langsung) terhadap kegiatan lainnya.

4. Teori Tempat Sentral

Teori tempat sentral dikemukakan oleh Walter Christaller (1933), seorang ahli geografi dari Jerman.Teori ini didasarkan pada lokasi dan pola persebaran permukiman dalam ruang. Dalam suatu ruang kadang ditemukan persebaran pola permukiman desa dan kota yang berbeda ukuran luasnya. Teori pusat pertumbuhan dari Christaller ini diperkuat oleh pendapat August Losch (1945) seorang ahli ekonomi Jerman.

\section{Pengertian, Ciri-Ciri dan Peran Desa sebagai Pusat Pertumbuhan}

1. Pengertian Desa Pusat Pertumbuhan

Desa Pusat Pertumbuhan (DPP) adalah suatu desa yang mempunyai kegiatan utama pertanian termasuk pengelolaan SDA, dengan fungsi dan perannya sebagai berikut:

a. Merupakan Jasa Pelayanan resmi tingkat desa atau kecamatan

b. Merupakan pusat jasa pelayanan social.

c. Sebagai tempat permukiman

d. Mempunyai potensi sebagai tempat kegiatan ekonomi daerah penunjangnya (Hinterland)

e. Mempunyai akses yang baik menuju dan dari daerah hinterlandnya

Dengan kata lain DPP merupakan desadesa yang memiliki potensi sebagai pusat pertumbuhan dan merupakan satuan permukiman desa yang belum termasuk klasifikasi perkotaan. DPP merupakan usaha mengkonsolidasikan dan pengantisipasian kebutuhan masyarakat desa yang langsung dapat memacu tumbuh berkembangnya potensi dan usaha ekonomi desa tersebut.

Penentuan suatu desa menjadi desa pusat pertumbuhan didasarkan pada pertimbangan bahwa pertumbuhan tidak akan terjadi di semua tempat secara spontanitas. Pertumbuhan mulai muncul di titik-titik yang mempunyai keuntungan yang tinggi dengan intensitas berbeda, menyebar melalui saluran-saluran yang luas dan mempunyai pengaruh yang berbeda pada keseluruhan ekonomi. Pengaruh titik-titik tumbuh kawasan belakangnya sangat bergantung pada efek yang menyokong (favourable effect) yang menetes ke hinterland dan efek yang tidak menyokong (unfavourable effect) sebagai akibat daya tarik titik tumbuh tersebut

Secara teoritis, desa pusat pertumbuhan harus menjadi tempat berkumpulnya kegiatan yang merupakan penggerak dinamis pertumbuhan ekonomi, serta mempunyai keterkaitan produksi, baik secara vertical maupun secara horizontal. Di sisi lain DPP merupakan pusat yang memberikan pelayanan di dalam penyediaan barang dan jasa.

2. Peranan Desa Pusat Pertumbuhan

Desa sebagai unit administrasi pemerintah, ekonomi dan sosial yang terkecil telah diberikan perhatian dan peranan yang sangat tinggi untuk dilakukan perkuatan sehingga dapat menjadi desa yang mandiri. Seperti halnya dalam Konsep pengembangan wilayah, maka pembangunan pedesaan harus memiliki 3 unsur fundamental, yaitu adanya pusat, wilayah pengaruh, dan jaringan transportasi

Desa yang memiliki potensi dan kemampuan pertumbuhan, selanjutnya disebut sebagai Desa Pusat Pertumbuhan (DPP). Desa- desa yang termasuk dalam jangkauan pengaruh desa pusat pertumbuhan yang disebut desa hinterland (DH). Jangkauan pelayanan pembangunan dari DPP ke DH dalam suatu wilayah pengaruh disebut sebagai kawasan pusat pertumbuhan desa, karena jumlah desa yang difungsikan sebagai DPP terbatas atau terpilih, oleh karena itu disebut sebagai Kawasan Terpilih Pusat Pengembangan Desa (KTP2D).

Pembangunan diarahkan pada pengembangan sektor-sektor unggulan dan penunjang pada DPP dan desa-desa hinterland (DH). Pengembangan dan pembangunan sektor tersebut akan meningkatkan interaksi kegiatan - kegiatan pembangunan di seluruh KTP2D.

Kriteria Penentuan Lokasi Desa Pusat Pertumbuhan

Kriteria penentuan lokasi desa pusat pertumbuhan menurut Departemen 
Pekerjaan Umum Direktorat Cipta Karya, Direktorat Perumahan (2006) antara lain sebagai berikut:

1. Kriteria Utama

a. Mempunyai Leading sector

b. Tidak rawan bencana

c. Luas lahan yang cukup dan layak untuk menampung kegiatan, fungsi, dan peranan pusat pertumbuhan

d. Bukan wilayah ibukota kecamatan

e. Memiliki kecenderungan untuk berkembang sebagai pusat pelayanan

f. Memiliki potensi tertentu yang dapat dikembangkan, misalnya pariwisata, agrowisata, dan sentra produksi

g. Lokasi yang strategis, mempunyai akses yang memadai untuk transportasi lokal dan wilayah sekitarnya

2. Kriteria Penunjang

a. Didukung oleh suatu pemerintahan yang berjalan baik, mempunyai kelembagaan yang berwawasan positif terhadap pembangunan.

b. Ada embrio kegiatan positif yang masih memerlukan dukungan prasarana dan sarana.

c. Tingkat kepadatan dan demografis yang menguntungkan

d. Tidak harus desa Swasembada

e. Minimal 3 (tiga) desa yang bersinergi langsung dengan DPP.

\section{METODE PENELITIAN}

Lokasi Penelitian, penelitian dilakukan di Kecamatan Lembar Kabupaten Lombok Barat.

\section{Jenis dan Sumber Data}

\section{Jenis Data}

a. Data kuantitatif, meliputi data: Jumah Sarana dan Prasarana, Jarak desa pusat kecamatan dan kepadatan penduduk,

b, Data kualitatif meliputi data: Kondisi Sarana dan Prasarana, Sektor ekonomi potensial, dll

2. Sumber Data.

a Data primer, meliputi Pola penggunaaan lahan, Kondisi sarana dan prasarana .

b.Data sekunder, adalah data yang diperoleh dari instansi terkait dan pemerintah daerah seperti Dinas PU, BPS, BAPPEDA, Kantor Kecamatan, Kantor Desa dan lain-lain yang dianggap perlu. Data tersebut berupa: Data Kependudukan, Peta lokasi, dan lain-lain

\section{Metode Pengumpulan Data}

Metode pengumpulan data yang digunakan adalah Metode Survey instansional, Teknik dokumentasi dan Telaah Kepustakaan,

\section{Metode Pengolahan dan Analisis Data}

Teknik analisis yang digunakan dalam penelitian ini sebagai berikut:

\section{Analisis Kualitatif}

Metode analisis ini bersifat deskriptif yang dilakukan sesuai dengan tujuan penelitian dengan menggambarkan atau menguraikan secara jelas kondisi yang terjadi di lokasi penelitian. Analisis ini digunakan untuk menentukan Kawasan Terpilih Pusat Pengembangan Desa (KTP2D) Kecamatan Lembar dengan menganalisis kondisi fisik dasar masing -masing desa untuk mengidentifikasi desa - desa yang mempunyai kemiripan atau kesamaan dalam wilayah pengembangan Desa Pusat Pertumbuhan.

\section{Analisis Kuantitatif}

Metode analisis ini menggunakan angkaangka statistik untuk menguatkan uraian deskriptif terhadap data yang telah diperoleh. Dalam penelitian ini, metode ini digunakan untuk mengidentifikasi ketersediaan sarana dan prasarana masing masing desa di Kecamatan Lembar dan untuk menentukan desa yang sesuai untuk dikembangkan sebagai Desa Pusat Pertumbuhan di Kecamatan Lembar..

\section{a. Analisis Ketersediaan Sarana dan Prasarana}

Analisis ini digunakan untuk mengidentifikasi ketersediaan sarana dan prasarana masing - masing desa di Kecamatan Lembar dengan standar kebutuhan sarana dan prasarana permukiman. Standar kebutuhan sarana dan prasarana yang sesuai dengan konsep pedoman perencanaan lingkungan pemukiman Kota Departemen PUPR (1999).

Interpretasi penilaian untuk memilih Desa Pusat Pertumbuhan (DPP) berdasarkan total 7 (tujuh) variabel di atas dilakukan dengan melakukan penskoringan atau pembobotan dengan kategori sebagai berikut: 
a. Nilai 73 - 100 dipilih sebagai desa pusat pertumbuhan

b. Nilai 45-72 dipilih sebagai desa potensial untuk menjadi pusat pertumbuhan

c. Nilai $<45$ merupakan desa biasa (sub pusat)

\section{HASIL DAN PEMBAHASAN}

\section{Gambaran Umum Lokasi Penelitian.}

\section{Kondisi Geografis}

Kecamatan Lembar merupakan salah satu dari sepuluh Kecamatan yang ada di Kabupaten Lombok Barat. Kecamatan ini berbatasan langsung dengan Kecamatan Gerung di sebelah Utara, Kabupaten
Lombok Tengah di sebelah Timur, Kecamatan Sekotong di sebelah Selatan serta Selat Lombok di sebelah Barat (Lembar Dalam Angka, 2016).

Kecamatan Lembar memiliki sepuluh desa dengan Desa Lembar Selatan sebagai ibu kota Kecamatan. Untuk lebih jelasnya dapat dilihat pada tabel 1.

Luas wilayah Kecamatan Lembar adalah 77, $19 \mathrm{~km}^{2}$ atau sekitar $15 \%$ dari luas wilayah Kabupaten Lombok Barat. Desa yang terluas wilayahnya adalah Desa Mareje yaitu 11, 76 $\mathrm{km}^{2}$, sedangkan desa yang tersempit wilayahnya adalah Desa Jembatan Kembar Timur yaitu $2,81 \mathrm{~km}^{2}$. Dari 10 desa ini, terdiri dari desa pantai, desa perbukitan dan desa pertanian

Tabel 1. Luas Wilayah Kecamatan Lembar Tahun 2015

\begin{tabular}{|l|l|l|}
\hline No & Nama Desa & Luas \\
\hline 1 & Desa Mareje & $11,76 \mathrm{Km}^{2}$ \\
\hline 2 & Desa Sekotong Timur & $11,01 \mathrm{Km}^{2}$ \\
\hline 3 & Desa Lembar & $5,71 \mathrm{Km}^{2}$ \\
\hline 4 & Desa Jembatan Kembar & $4,93 \mathrm{Km}^{2}$ \\
\hline 5 & Desa Labuan Tereng & $11,62 \mathrm{Km}^{2}$ \\
\hline 6 & Desa Mareje Timur & $11,03 \mathrm{Km}^{2}$ \\
\hline 7 & Desa Lembar Selatan & $5,88 \mathrm{Km}^{2}$ \\
\hline 8 & Desa Jembatan Gantung & $4,98 \mathrm{Km}^{2}$ \\
\hline 9 & Desa Jembatan Kembar Timur & $2,81 \mathrm{Km}^{2}$ \\
\hline 10 & Desa Eyat Mayang & $7,46 \mathrm{Km}^{2}$ \\
\hline & Total & $77,19 \mathrm{Km}^{2}$ \\
\hline
\end{tabular}

Sumber: Kecamatan Lembar dalam Angka Tahun 2016

Masing masing desa memiliki karakter masing masing. Desa Lembar, Sekotong Timur, Desa Lembar Selatan dan Desa Labuan Tereng merupakan desa yang mempunyai wilayah pantai. Desa yang wilayahnya terdiri dari perbukitan adalah Desa Mareje, Mareje Timur, dan Desa Eyang Mayang. Sedangkan desa desa lainnya adalah desa dengan pertanian dan. Perkebunan.

\section{Potensi Desa}

Desa di Kecamatan Lembar masih dikategorikan sebagai Desa Swadaya, Swakarya dan Desa Swasembada.. Dari 10 desa yang ada, 5 diantaranya dikategorikan sebagai desa Swadaya artinya adalah desa yang masyarakatnya telah mampu memenuhi kebutuhan sendiri. Penduduknya jarang dan kurang berkomunikasi dengan masyarakat luar.
Desa Mareje, Desa Sekotong Timur dan Desa Labuan Tereng termasuk dalam klasifikasi desa Swakarya artinnya adalah desa yang masyarakatnya sudah lebih maju dibanding dengan desa swadaya. Selain untuk memenuhi kebutuhannya sendiri, kelebihan produkdi yang dihasilkan penduduk sudah mulai dijual ke daerah lain.

3. Fasilitas Untuk Menunjang Perkembangan Produksi dan Jasa

a. Fasilitas Pasar

Salah satu unsur dalam perencanaan wilayah adalah Pasar. Pasar disamping sebagai tempat / fasilitas untuk menjual dan membeli keperluan sehari hari atau barang konsumsi juga merupakan fasilitas untuk mencari kerja bagi kelompok yang lain. Hasil survey menunjukkan bahwa jumlah pasar di 
Kecamatan Lembar 4 buah, yaitu di Desa Mareje Timur, Lembar Selatan, Jembatan Kembar Timur dan Desa eyang Mayang. Kalau dilihat dari jumlah penduduk di Desa Mereje yang jauhnya $12 \mathrm{Km}$ dari ibu kota Kecamatan, seharusnya memiliki pasar. Berati masyarakatnya ke pasar terdekat untuk membeli barang keperluannya dan menjual hasil buminya.

Jumlah kios dan Warung lumayan banyak dan, hampir setiap desa ada. Dari data juga kita dapat melihat bahwa Desa Lembar Selatan memiliki fasilitas pasar, kios dan warung terbanyak, yakni sejumlah 268 uni atau 32,68 persen dari jumlah keseluruhan fasilitas ekonomi yang ada di Kecamatan Lembar. Ini sesuai dengan jumlah penduduknya yang terbanyak di Kecamatan Lembar, mencapi 2.445 atau 17,35 persen dari keseluruhan penduduk Kecamatan Lembar yang berjumlah 14.089 jiwa.

Desa Mareje merupakan desa yang memiliki fasilitas kios dan warung tersedikit yakni 26 unit, ini juga sesuai jumlah penduduknya yang sedikit yakni berjumlah 1.104 jiwa.

b. Sarana Penerangan

Listrik merupakan sumber energy yang diperlukan bagi manusia. Selain sebagai salah satu sumber penerangan, listrik juga diperlukan untuk menunjang kegiatan sehari hari. Namun sayangnya masih belum semua rumah tangga di desa kecamatan Lembar dapat menikmat energi listrik. Rumah tangga yang tidak dialiri listrik PLN menggunakan Generator / Genset dan alat penerang lainnya.

1. Sarana Komunikasi

Kecamatan Lembar sudah terlayani berbagai macam alat komunikasi antara lain Kantor Pos pembantu, TV, Radio/tape dan telpon. Sedangkan jaringan telekomunikasi berupa jaringan telpon selular sudah merata diseluruh desa. Untuk lebih jelasnya dapat dilihat pada Tabel 4.6. Dari tabel tersebut kita dapat melihat bahwa di Kecamatan Lembar,hanya ada 1 kantor pos yaitu di Desa lembar. Alat komunikasi yang lain seperti Radio / tape dan TV hampir merara diseluruh desa, sementara telfon rumah hanya ada di Desa Lembar dan Jembatan Kembar.

Hampir semua desa ada TV, juga hamper semua Rumah Tangga memiliki TV, alasan mereka supaya tidak ketinggalan informasi dalam segala hal. Alat komunikasi berupa telfon ada pada dua desa, yaitu Desa Lembardam Jembatan Kembar. Karena hampir semua RT baik di desa maupun di Kota sudah jarang memiliki telfon rumah, kecuali kantor dan perusahaan, ini disebabkan karena sudah memasyarakatnya pemanfaatan telpon seluler yang lebih mudah dan murah ( pulsanya ).

2. Lembaga Keuangan

Kecamatan Lembar juga dilengkapi sarana lembaga keuangan untuk membantu memenuhi kebutuhan penduduk Kecamatan Lembar.Lembaga Keuangan yang ada berupa; KUD, Bank, Kospin dan ;Pegadaiana.

Dari data yang ada, menunjukkan bahwa Koperasi Unit Desa (KUD), di Kecamatan Lembar ada 2 unit, yaitu pada Desa Lembar dan Desa Jembatan Kembar. Koperasi Simpan Pinjam (Kospin) ada 7 unit dan tersebar pada 4 desa, yaitu Desa Jembatan Kembar (3 unit), Mareje Timur (1 unit), Jembatan Gantung ( 2 unit ) dan Jembatan Kembar Timur (1unit ). Pegadaian ada 1 unit, terletak di Desa Lembar Selatan.sementara Bank tidak ada di Kecamatan Lembar.

3. Kelembagaan Masyarakat

Kelembagaan masyarakat yang ada di Kecamatan Lembar adalah BPD. Untuk lebih jelasnya dapat dilihat pada Tabel 2. berikut: 
Tabel 2 Banyaknya Kelembagaan Masyarakat di Kecamatan Lembar Tahun 2016

\begin{tabular}{|l|l|l|l|l|}
\hline No & Desa & BPD & PKK & Jumlah ( unit ) \\
\hline 1. & Mareje & 11 & 31 & 42 \\
2 & Sekotong Timur & 9 & 18 & 27 \\
3 & Lembar & 9 & 27 & 36 \\
4 & Jembatan Kembar & 11 & 30 & 41 \\
5 & Labuan Tereng & 11 & 22 & 33 \\
6 & Mareje Timur & 11 & 22 & 33 \\
7 & Lembar Selatan & 11 & 33 & 44 \\
8 & Jembatan Gantung & 7 & 21 & 28 \\
9 & Jembatan Kembar Timur & 7 & 18 & 25 \\
10 & Eyang Mayat & 11 & 22 & 33 \\
\hline & Jumlah & & 244 & 342 \\
\hline
\end{tabular}

Kecamatan Lembar dalam Angka Tahun 2016

Seluruh desa memiliki lembaga masyarakat yakni BPD dan PKK, karenaini merupakan lembaga wajib yang harus ada dalamsebuah desa untuk memperlancar operasional desa yang bersangkutan. Desa yang memiliki kelembagaan masyarakat terbanyak adalah Desa Lembar Selatan, berupa PKK sebanyak 30 dan BPD 11. Sedangkan desa yang tersedikit memiliki lembaga kemasyarakatan adalah desa Jembatan Kembar Timur.

1. Fasilitas untuk Pelayanan Jasa - Jasa

a. Sumber Air Bersih

Tingkat pelayanan kebutuhan air bersih pada Kecamatan Lembar sudah cukup baik. Sumber air bersih di Kecamatan ini berasal dari PAM dan sumur ( sumur bantuan pemerintah, swadaya masyarakat dan sumur pribadi ). Ada 6 desa di Kecamatan Lembar yang sudah terlayani PAM.

Dari yang dikumpulan bahwa sampai saat ini ada 4 desa yang belum menikmati air bersih yang disediakan oleh PAM, yaitu Desa Mareje, DesaSekotong Timur, Desa Mareje Timur dan Desa Eyat Mayang. Masyarakat di desa desa ini menikmati air bersih dari sumur bantuan pemerintah, sumur swadaya masyarakat dan sumur pribadi Bahkan ada 2 desa yang tidak diketahui sumber air bersih yang masyarakatnya konsumsi. Ada 3 desa yang masyarakatnya hanya mengkonsumsi air yang disediakan oleh PAM, tampa ada sumber lain. Sedangkan Desa
Jembatan Kembar, semua sumber air terdesia. Desa Lembar Selatan sebagian besar masyarakatnya mengkonsumsi air yang disediakan oleh PAM.

b. Fasilitas Pendidikan

Untuk mendukung proses kegiatan belajar mengajar di Kecamatan Lembar, maka pemerintah setempat menyediakan beberapa fasilitas pendidikan bagi warga Kecamatan Lembar.

menunjukkan bahwa berdasarkan standar kebutuhan sarana permukiman, masih ada desa di Kecamatan Lembar yang belum memeliki fasilitas Pendidikan TK, yakni Desa Jembatan Gantung. Kalau dilihat dari jumlah penduduk, seharusnya Desa Jembatan Kembar memiliki TK 5 unit.

Untuk menjadi Desa Pusat Pertumbuhan, desa tersebut harus memiliki beberapa persyaratan yang harus dipenuhi. Untuk hasil perhitungan kebutuhan Fasilitas Kesehatandi Kecamatan Lembar berdasarkan standar kebutuhan sarana permukiman

c. Fasilitas Kesehatan

Untuk menunjang pelayanan dan peningkatan mutu kesehatan masyarakat Kecamatan Lembar maka pemerintah setempat menyediakan beberapa fasilitas kesehatan.

2. Kepadatan Penduduk

Kecamatan Lembar termasuk kecamatan yang memiliki jumlah penduduk yang padat di Kabupaten Lombok barat. 
Berdasarkan hasil pendataan penduduk di Kecamatan Lembar pada tahun 2015 tercatat penduduk sebanyak 48.548 jiwa dengan kepadatan penduduk sebanyak 326 jiwa per $\mathrm{km}^{2}$.

Desa yang terpadat adalah Desa Lembar Selatan dengan kepadatan 1.505 jiwa $/ \mathrm{Km}^{2}$, kemudian diikuti oleh Desa Jembatan Kembar Timur dengan kepadatan 1.436 jiwa / $\mathrm{Km}^{2}$. Sedangkan desa yang jarang penduduknya adalah Desa Mareje Timur dengan kepadatan 263 jiwa / $\mathrm{Km}^{2}$. Untuk lebih jelasnya dapat dilihat pada Tabel 3.

Tabel 3 Jumlah Penduduk, Luas Wilayah dan Kepadatan Penduduk di Kec. Lembar

\begin{tabular}{|l|l|r|r|r|}
\hline No & Desa & Jumlah penduduk & Luas Wilayah & Kepadatan / Km \\
\hline 1 & Mareje & 3.957 & 11,76 & 336 \\
\hline 2 & Sekotong Timur & 4.499 & 11,01 & 409 \\
\hline 3 & Lembar & 6.327 & 5,71 & 1.108 \\
\hline 4 & Jembatan Kembar & 4.052 & 4,93 & 822 \\
\hline 5 & Labuan Tereng & 5.307 & 11,62 & 457 \\
\hline 6 & Mareje Timur & 2.906 & 11,03 & 263 \\
\hline 7 & Lembar Selatan & 8.850 & 5,88 & 1.505 \\
\hline 8 & Jembatan Gantung & 6.179 & 4,98 & 1.241 \\
\hline 9 & Jembatan Kbr Timur & 4.036 & 2,81 & 1.436 \\
\hline 10 & Eyat Mayang & 2.434 & 7,46 & 326 \\
\hline Jumlah & 48.548 & 77,19 & 326 \\
\hline
\end{tabular}

Kecamatan Lembar dalam Angka Tahun 2016

Kecamatan Lembar mempunyai panjang lalan $\pm 162 \mathrm{~km}$, dengan kondisi permukaan jalan yang terdiri dari aspal.
Total panjang jalan aspal yaitu $73 \mathrm{~km}$, total panjang jalan diperkeras yaitu 54 $\mathrm{km}$, sedangkan total panjang jalan tanah adalah $35 \mathrm{~km}$. Untuk lebih jelasnya dapat dilihat pada Tabel 4. berikut:

Tabel 4 Fasilitas dan Kondisi Jalan di Kecamatan Lembar Tahun 2016

\begin{tabular}{|l|l|l|l|l|l|}
\hline \multirow{2}{*}{ No } & \multirow{2}{*}{ Desa } & \multicolumn{2}{|l|}{ Kondisi Jalan $(\mathrm{Km})$} & \multirow{2}{*}{ Jumlah $(\mathrm{Km})$} \\
\cline { 3 - 6 } & & Aspal & Diperkeras & Tanah & \\
\hline 1 & Mareje & 5 & 4 & 2 & 11 \\
\hline 2 & Sekotong Timur & 23 & 2 & 2 & 27 \\
\hline 3 & Lembar & 18 & - & 3 & 21 \\
\hline 4 & Jembatan Kembar & 10 & 3 & 3 & 16 \\
\hline 5 & Labuan Tereng & 8 & 30 & 10 & 48 \\
\hline 6 & Mareje Timur & 1 & 3 & 4 & 8 \\
\hline 7 & Lembar Selatan & 1 & 1 & 3 & 5 \\
\hline 8 & Jembatan Gantung & 2 & 2 & 2 & 6 \\
\hline 9 & Jembatan Kbr Timur & 2 & 2 & 2 & 6 \\
\hline 10 & Eyat Mayang & 3 & 7 & 4 & \\
\hline Jumlah & 73 & 54 & 35 & 162 \\
\hline
\end{tabular}

Sumber: Kecamatan Lembar dalam Angka Tahun 2016

Jalan yang diaspal panjangnya lebih kurang 73 $\mathrm{km}$ atau 45,06 persen dari keseluruhan jalan di Kecamatan Lembar. Jalan yang diperkeras sepanjang $54 \mathrm{Km}$ atau 33,33 persen, sedangkan jalan tanah sepanjang $35 \mathrm{Km}$ atau 21,6 persen, Jalan yang diperkeras sepanjang $54 \mathrm{Km}$ atau 55,55 persen berarti setengah dari jalan yang diperkeras di Kecamatan Lembar Sedangkan jalan tanah sepanjang di Desa 
Labuan Tereng sepanjang $35 \mathrm{Km}$ atau 21.60 persen. Jadi kondisi jalandi Desa Labuan Tereng masih dibawah standar karena 55,55 persen jalan masih jalan diperkeras dan hanya sekitar 10,95 persen jalan yang diaspal

a. Sarana Angkutan

Kecamatan Lembar memiliki 4 macam sarana angkutan yang terdiri dari 1 unit Dermaga / Pelabuhan, 2 unit Tambatan Perahu, 3 unit terminal dan tempat parkir 3 Dari hasil survey kita dapat melihat bahwa Desa Lembar Selatan sebagai Ibu Kota Kecamatan mempunyai tiga ( 3 ) macam sarana pengangkutan, yaitu, terminal, Tambatan perahu, terminal dan tempat parkir. Pelabuhan Lembar hanya ada di Desa Lembar, yang menghubungkan antara Pulau Lombok dan Pulau Bali ( Indonesia bagian barat) atau pintu masuk liwat laut di NTB

b. Jenis Angkutan Jenis Angkutan yang banyak terdapat di Kecamatan Lembar adalah mobil, sepeda motor, dan kapal.

c. Jarak Ibu Kota Kecamatan ke Desa Ibu Kota Kecamatan Lembar adalah Desa Lembar Selatan yang mempunyai jarak yang terdekat adalah Desa Labuan Tereng dengan jarak $1 \mathrm{~km}$.

Tabel 5 Jarak Ibu Kota Kecamatan Lembar ke Desa sekitarnya Tahun 2016

\begin{tabular}{|l|l|l|l|}
\hline No & Desa & lbu kota Kecamatan & Jarak $(\mathrm{Km})$ \\
\hline 1 & Mareje & Lembar Selatan & 12 \\
\hline 2 & Sekotong Timur & Lembar Selatan & 4 \\
\hline 3 & Lembar & Lembar Selatan & 3 \\
\hline 4 & Jembatan Kembar & Lembar Selatan & 2 \\
\hline 5 & Labuan Tereng & Lembar Selatan & 1 \\
\hline 6 & Mareje Timur & Lembar Selatan & 7 \\
\hline 7 & Lembar Selatan & Lembar Selatan & 0 \\
\hline 8 & Jembatan Gantung & Lembar Selatan & 3 \\
\hline 9 & Jembatan Kembar Timur & Lembar Selatan & 2 \\
\hline 10 & Eyat Mayang & Lembar Selatan & 5 \\
\hline
\end{tabular}

Sumber: Kecamatan Lembar dalam Angka Tahun 2016

Sedangkan desa yang terjauh dari ibu kota kecamatan adalah Mareje dengan jarak 12 $\mathrm{km}$.

\section{Analisis Ketersediaan Sarana dan Prasarana}

Berdasarkan analisis di atas, disimpulkan bahwa sarana dan prasarana yang ada di Kecamatan Lembar secara umum sudah cukup tersedia namun ada beberapa desa yang sarana dan prasarananya belum tersedia atau belum memenuhi standar yaitu:

1. Tidak tersedianya fasilitas pasar di Desa Mareje, Sekotong Timur, Lembar, Jembatan Kembar dan Desa Jembatan Gantung.

2. Fasilitas pendidikan seperti TK di Desa Jembatan Kembar Timur belum memenuhi standar kebutuhan sarana permukiman

3. Tidak tersedianya jaringan air bersih/ PDAM di Desa Mareje, Sekotong Timur dan Mereje Timur
4. Tidak tersedianya sarana keuangan di Desa Mareje, Sekotong Timur dan Eyat Mayang.

5. Kualitas jalan yang buruk di Desa Labuan Tereng dan Desa Mareje Timur.

6. Sarana persampahan di kecamatan ini belum tersedia,

ketersediaaan dari setiap indikator yang ada, dimana nilai 5 berarti kondisi sarana dan prasarana mendukung untuk pembentukan Desa Pusat Pertumbuhan (DPP), nilai 3 yang berarti kurang mendukung untuk pembentukan Desa Pusat Pertumbuhan (DPP),sedangkan nilai 1 tidak mendukung untuk pembentukan Desa Pusat Pertumbuhan (DPP).

Analisis Penentuan Kawasan Terpilih Pusat Pengembangan Desa (KTP2D)

Kawasan Terpilih Pusat Pengaembangan Desa (KTP2D) merupakan kawasan pusat pengembangan desa yang terdiri dari beberapa desa dengan potensi dan kondisi 
geografi yang hampir mirip. Dari aspek fisik dasar wilayah atau geografi seluruh desa ini mempunyai karakter fisik yang hampir mirip yaitu berada pada wilayah datar dan landai serta memiliki intensitas curah hujan yang sama. Selain itu, seluruh desa ini mempunyai potensi ekonomi wilayah yang saling berhubungan yaitu potensi pertanian, perkebunan, perikanan dan peternakan. Namun berdasarkan analisis ketersediaan sarana dan prasarana di atas, dari 10 desa yang ada di Kecamatan Lembar hanya ada 4 desa yang memenuhi kriteria KTP2D yaitu Desa Lembar, Jembatan Kembar, Lembar Selatan, dan Desa Jembatan Kembar Timur.

Analisis Penentuan Desa Pusat Pertumbuhan Berdasarkan penjelasan sebelumnya bahwa penentuan suatu desa sebagai pusat pertumbuhan sangat terkait dengan penilaian 7 (tujuh) variabel, yaitu potensi desa, fasilitas untuk menunjang perkembangan produksi dan jasa, kelembagaan masyarakat, fasilitas untuk pelayanan jasa - jasa, jumlah penduduk, aksesibilitas, serta penilaian berdasarkan desa bebas dari gangguan bencana alam dan penyakit menular.

a. Potensi Desa

Indikator yang digunakan dalam variabel Potensi Desa adalah klasifikasi desa, jumlah domian rumah, pengelolaan kegiatan petanian, jumlah pabrik, dan sektor ekonomi potensial. Hasil analisis penilaian dan pembobotan variabel Potensi Desa dapat dilihat pada Tabel 6 berikut:

Tabel 6 Penilaian Berdasarkan Potensi Desa

\begin{tabular}{|c|c|c|c|c|c|c|}
\hline \multirow[b]{2}{*}{ No } & \multirow[b]{2}{*}{ Variabel } & \multirow[b]{2}{*}{ Penilaian } & \multicolumn{4}{|c|}{ Desa / Kelurahan } \\
\hline & & & Lembar & $\begin{array}{l}\text { Jembatan } \\
\text { Kembar }\end{array}$ & $\begin{array}{l}\text { Lembar } \\
\text { Selatan }\end{array}$ & $\begin{array}{l}\text { Jembatan } \\
\text { Kembar } \\
\text { Timur }\end{array}$ \\
\hline 1. & \begin{tabular}{ll}
\multicolumn{2}{l}{ Klasifikasi Desa } \\
a. & Swadaya \\
b. & Swakarya \\
c. & Swasembada \\
d. & Lainnya
\end{tabular} & $\begin{array}{l}1 \\
2 \\
3 \\
0\end{array}$ & 3 & 3 & 1 & 1 \\
\hline 2. & $\begin{array}{l}\text { Jumlah Dominan } \\
\text { Rumah } \\
\text { a. Pertanian/pe } \\
\text { rikanan } \\
\text { b. Industri } \\
\text { Kerajinan } \\
\text { c. Perdagangan } \\
\text { dan jasa } \\
\text { d. Lainnya }\end{array}$ & $\begin{array}{l}2 \\
4 \\
3 \\
1\end{array}$ & 3 & 3 & 2 & 1 \\
\hline 3. & $\begin{array}{l}\text { Pengelolaan } \\
\text { Kegiatan Pertanian } \\
\text { a. Organisasi } \\
\text { pertanian } \\
\text { b. Badan usaha } \\
\text { / perusahaan } \\
\text { c. Tidak ada } \\
\text { organisasi }\end{array}$ & $\begin{array}{l}3 \\
5 \\
0\end{array}$ & 0 & 0 & 0 & 0 \\
\hline 4. & $\begin{array}{l}\text { Jumlah Pabrik } \\
\text { a. } \quad \geq 5 \text { buah } \\
\text { b. } \quad 2-4 \text { buah } \\
\text { c. } \quad \leq 2 \text { buah }\end{array}$ & $\begin{array}{l}5 \\
3 \\
1\end{array}$ & 1 & 1 & 1 & 1 \\
\hline 5. & $\begin{array}{ll}\text { Sektor } & \text { Ekonomi } \\
\text { Potensial } & \end{array}$ & & & 1 & 1 & 1 \\
\hline
\end{tabular}




\begin{tabular}{|l|l|l|l|l|l|l|}
\hline \multirow{2}{*}{ No } & \multirow{2}{*}{ Variabel } & Penilaian & Lembar & $\begin{array}{l}\text { Jembatan } \\
\text { Kembar }\end{array}$ & $\begin{array}{l}\text { Lembar } \\
\text { Selatan }\end{array}$ & $\begin{array}{l}\text { Jembatan } \\
\text { Kembar } \\
\text { Timur }\end{array}$ \\
\cline { 3 - 6 } & $\begin{array}{l}\text { a. Sawah/perkebuna } \\
\text { n/perikanan/lahan } \\
\text { kering } \\
\text { b. Industri kecil } \\
\text { c. Industri besar dan } \\
\text { sedang } \\
\begin{array}{l}\text { d. Perdagangan dan } \\
\text { jasa lain }\end{array}\end{array}$ & 1 & 5 & 1 & & \\
\hline Jumlah & 22 & 8 & 8 & 5 & 4 \\
\hline Bobot (\%) & 100 & 36 & 36 & 23 & 18 \\
\hline
\end{tabular}

Sumber: Hasil Analisis, 2017

Berdasarkan hasil analisis pada Tabel 6 di atas menunjukkan bahwa Desa Lembar dan Desa Jembatan Kembar mempunyai bobot yang lebih tinggi dibanding desa lainnya yaitu 36 . Jadi potensi yang terdapat di Desa Lembar dan Desa Jembatan Kembar mendukung daerah ini untuk dijadikan sebagai Desa Pusat pertumbuhan (DPP) dalam KTP2D di Kecamatan Lembar.

a. Fasilitas untuk Menunjang Perkembangan Produksi dan Jasa

Indikator yang digunakan dalam variabel Fasilitas untuk Menunjang Perkembangan Produksi dan Jasa adalah fasilitas pasar, sarana penerangan, sarana komunikasi, dan perkreditan, Hasil analisis penilaian dan pembobotan variabel Fasilitas untuk Menunjang Perkembangan Produksi dan Jasa dapat dilihat pada Tabel 7

Berdasarkan hasil analisis pada Tabel 7 menunjukkan bahwa Desa Lembar mempunyai bobot yang lebih rendah dibanding desa lainnya yaitu 55. Sedangkan desa lainnya seperti Desa Lembar Selatan dan Desa Jembatan Kembar Timur. mempunyai nilai bobot yang sama yaitu 80 .. Jadi Fasilitas untuk Menunjang Perkembangan Produksi dan Jasa yang terdapat di Desa Lembar Selatan dan Desa Jembatan Timur mendukung daerah ini untuk dijadikan sebagai Desa Pusat pertumbuhan (DPP) dalam KTP2D di Kecamatan Lembar

Tabel 7 Penilaian Berdasarkan Fasilitas untuk Menunjang Perkembangan Produksi dan Jasa

\begin{tabular}{|c|c|c|c|c|c|c|}
\hline \multirow[b]{2}{*}{ No. } & \multirow[b]{2}{*}{ Variabel } & \multirow[b]{2}{*}{$\begin{array}{l}\text { Peni } \\
\text { laian }\end{array}$} & \multicolumn{4}{|c|}{ Desa / Kelurahan } \\
\hline & & & Lembar & $\begin{array}{l}\text { Jembatan } \\
\text { Kembar }\end{array}$ & $\begin{array}{l}\text { Lembar } \\
\text { Selatan }\end{array}$ & $\begin{array}{l}\text { Jembatan } \\
\text { Kembar } \\
\text { Timur }\end{array}$ \\
\hline 1. & $\begin{array}{l}\text { Fasilitas Pasar } \\
\text { a. Pasar/pertokoan/pasar } \\
\text { khusus } \\
\text { b. Tidak ada }\end{array}$ & $\begin{array}{l}5 \\
0\end{array}$ & 0 & 0 & 5 & 5 \\
\hline 2. & $\begin{array}{l}\text { Sarana Penerangan } \\
\text { a. Jumlah RT dilayani PLN } \\
\text { b. Jumlah RT dilayani non PLN } \\
\text { c. Lainnya }\end{array}$ & $\begin{array}{l}5 \\
3 \\
1\end{array}$ & 5 & 5 & 5 & 5 \\
\hline 3. & \begin{tabular}{ll}
\multicolumn{2}{l}{ Sarana Komunikasi } \\
a. & Telepon umum/wartel \\
b. & Telepon RT/seluler \\
c. & Tidak ada
\end{tabular} & $\begin{array}{l}5 \\
3 \\
0\end{array}$ & 3 & 3 & 3 & 3 \\
\hline
\end{tabular}




\begin{tabular}{|c|c|c|c|c|c|c|}
\hline \multirow[b]{2}{*}{ No. } & \multirow[b]{2}{*}{ Variabel } & \multirow[b]{2}{*}{$\begin{array}{l}\text { Peni } \\
\text { laian }\end{array}$} & \multicolumn{4}{|c|}{ Desa / Kelurahan } \\
\hline & & & Lembar & $\begin{array}{l}\text { Jembatan } \\
\text { Kembar }\end{array}$ & $\begin{array}{l}\text { Lembar } \\
\text { Selatan }\end{array}$ & $\begin{array}{l}\text { Jembatan } \\
\text { Kembar } \\
\text { Timur }\end{array}$ \\
\hline 4. & $\begin{array}{l}\text { Perkreditan } \\
\text { a. Bank } \\
\text { b. KUD } \\
\text { c. Koperasi lainnya } \\
\text { d. Tidak ada }\end{array}$ & $\begin{array}{l}5 \\
3 \\
3 \\
0\end{array}$ & 3 & $\begin{array}{l}3 \\
3\end{array}$ & 3 & 3 \\
\hline \multicolumn{2}{|c|}{ Jumlah } & 20 & 11 & 14 & 16 & 16 \\
\hline \multicolumn{2}{|c|}{ Bobot (\%) } & 100 & 55 & 70 & 80 & 80 \\
\hline
\end{tabular}

Sumber: Hasil Analisis, 2017

Fasilitas untuk Pelayanan Jasa - Jasa

Indikator yang digunakan dalam variabel Fasilitas untuk Pelayanan Jasa - Jasa adalah sumber air bersih desa, sarana sanitasi lingkungan (persampahan), fasilitas pendidikan, fasilitas kesehatan, dan fasilitas rekreasi. Hasil analisis penilaian dan pembobotan variabel Fasilitas untuk Pelayanan Jasa - Jasa dapat dilihat pada Tabel 8. Berdasarkan hasil analisis pada Tabel 8 menunjukkan bahwa Desa Jembatan Kembar
Timur mempunyai bobot yang lebih rendah dibanding desa lainnya yaitu 43. Sedangkan desa lainnya seperti Desa Lembar, Desa Jembatan Kembar dan Desa Lembar Selatan mempunyai bobot yang sama yaitu 53 Jadi Fasilitas untuk Pelayanan Jasa - Jasa yang terdapat di Lembar, Jembatan Kembar dan Desa Lembar Selatan. mendukung daerah ini untuk dijadikan sebagai Desa Pusat pertumbuhan (DPP) dalam KTP2D di Kecamatan Lembar.

Tabel 8 Penilaian Berdasarkan Fasilitas untuk Pelayanan Jasa - Jasa

\begin{tabular}{|c|c|c|c|c|c|c|}
\hline \multirow[b]{2}{*}{ No. } & \multirow[b]{2}{*}{ Variabel } & \multirow[b]{2}{*}{ Penilaian } & \multicolumn{4}{|c|}{ Desa / Kelurahan } \\
\hline & & & Lembar & $\begin{array}{l}\text { Jembatan } \\
\text { Kembar }\end{array}$ & $\begin{array}{l}\text { Lembar } \\
\text { Selatan }\end{array}$ & $\begin{array}{l}\text { Jembatan } \\
\text { Kembar } \\
\text { Timur }\end{array}$ \\
\hline 1. & $\begin{array}{l}\text { Sumber Air Bersih } \\
\text { a. PAM } \\
\text { b. Air sumur } \\
\text { c. Lainnya (sungai } \\
\text { dan air hujan) } \\
\end{array}$ & $\begin{array}{l}5 \\
3 \\
1\end{array}$ & 5 & 5 & 5 & 1 \\
\hline 2. & $\begin{array}{l}\text { Sarana Sanitasi } \\
\text { Lingkungan / sampah } \\
\text { a. Diangkut dengan truk } \\
\text { ke TPA } \\
\text { b. Lainnya (tanpa lokasi } \\
\text { pembuangan) }\end{array}$ & $\begin{array}{l}2 \\
1\end{array}$ & 1 & 1 & 1 & 1 \\
\hline 3. & $\begin{array}{l}\text { Fasilitas Pendidikan } \\
\text { (TK/SD/SLTP/SLTA/Kejur } \\
\text { uan sederajat, } \\
\text { Akademi/Universitas) } \\
\text { a. }<3 \\
\text { b. } 3-4 \\
\text { c. }>5\end{array}$ & $\begin{array}{l}1 \\
3 \\
5\end{array}$ & 3 & 3 & 3 & 3 \\
\hline 4. & $\begin{array}{l}\text { Fasilitas Kesehatan } \\
\text { a. Rumah sakit/RSB } \\
\text { b. Puskesmas/pustu } \\
\text { c. Poliklinik }\end{array}$ & $\begin{array}{l}5 \\
3 \\
1\end{array}$ & 1 & 1 & 1 & 3 \\
\hline
\end{tabular}




\begin{tabular}{|c|c|c|c|c|c|c|}
\hline \multirow[b]{2}{*}{ No. } & \multirow[b]{2}{*}{ Variabel } & \multirow[b]{2}{*}{ Penilaian } & \multicolumn{4}{|c|}{ Desa / Kelurahan } \\
\hline & & & Lembar & $\begin{array}{l}\text { Jembatan } \\
\text { Kembar }\end{array}$ & $\begin{array}{l}\text { Lembar } \\
\text { Selatan }\end{array}$ & $\begin{array}{l}\text { Jembatan } \\
\text { Kembar } \\
\text { Timur }\end{array}$ \\
\hline 5. & $\begin{array}{l}\text { Fasilitas Rekreasi } \\
\text { a. bioskop/teater } \\
\text { b. taman hiburan } \\
\text { c. lainnya }\end{array}$ & $\begin{array}{l}2 \\
1 \\
0\end{array}$ & 0 & 0 & 0 & 0 \\
\hline \multicolumn{2}{|c|}{ Jumlah } & 19 & 10 & 10 & 10 & 8 \\
\hline \multicolumn{2}{|c|}{ Bobot (\%) } & 100 & 53 & 53 & 53 & 42 \\
\hline
\end{tabular}

Sumber: Hasil Analisis, 2017

a. Jumlah Penduduk Indikator yang digunakan dalam variabel Jumlah Penduduk adalah kepadatan penduduk Hasil analisis penilaian dan pembobotan variabel Jumlah Penduduk dapat dilihat pada Tabel 9.

Tabel 9 Penilaian Berdasarkan Jumlah Penduduk

\begin{tabular}{|c|c|c|c|c|c|c|}
\hline \multirow[b]{2}{*}{ No. } & \multirow[b]{2}{*}{ Variabel } & \multirow[b]{2}{*}{ Penilaian } & \multicolumn{4}{|c|}{ Desa / Kelurahan } \\
\hline & & & Lembar & $\begin{array}{l}\text { Jembatan } \\
\text { Kembar }\end{array}$ & $\begin{array}{l}\text { Lembar } \\
\text { Selatan }\end{array}$ & $\begin{array}{l}\text { Jembatan } \\
\text { Kembar } \\
\text { Timur }\end{array}$ \\
\hline 1. & $\begin{array}{l}\text { Kepadatan } \\
\text { penduduk } \\
\text { a. } \leq 25 \mathrm{jiwa} / \mathrm{km}^{2} \\
\text { b. } 25-49 \mathrm{jiwa} / \mathrm{km}^{2} \\
\text { c. } \geq 50 \mathrm{jiwa} / \mathrm{km}^{2}\end{array}$ & $\begin{array}{l}1 \\
3 \\
5\end{array}$ & 5 & 5 & 5 & 5 \\
\hline \multicolumn{2}{|c|}{ Jumlah } & 5 & 5 & 5 & 5 & 5 \\
\hline \multicolumn{2}{|c|}{ Bobot (\%) } & 100 & 100 & 100 & 100 & 100 \\
\hline
\end{tabular}

Sumber: Hasil Analisis, 2017

Berdasarkan hasil analisis pada Tabel 9 di atas menunjukkan bahwa seluruh desa mempunyai nilai bobot yang sama yaitu 100 . Jadi Jumlah Penduduk yang terdapat di desa desa ini mendukung daerah ini untuk dijadikan sebagai Desa Pusat pertumbuhan (DPP) dalam KTP2D di Kecamatan Lembar

a. Aksesibilitas

Indikator yang digunakan dalam variabel Aksesibilitasadalah kualitas jalan, sarana angkutan, moda angkutan, dan jarak pusat kecamatan dengan kecamatan terdekat, Hasil analisis penilaian dan pembobotan variabel Aksesibilitas dapat dilihat pada Tabel 10.

Berdasarkan hasil analisis pada Tabel 10. menunjukkan bahwa Desa Lembar mempunyai bobot yang lebih tinggi dibanding desa / lainnya yaitu 100. Jadi, Aksesibilitas yang terdapat di Desa Lembar.mendukung daerah ini untuk dijadikan sebagai Desa Pusat pertumbuhan (DPP) dalam KTP2D di Kecamatan Lembar

Tabel 10 Penilaian Berdasarkan Aksesibilitas

\begin{tabular}{|c|c|c|c|c|c|c|}
\hline \multirow[b]{2}{*}{ No. } & \multirow[b]{2}{*}{ Variabel } & \multirow[b]{2}{*}{ Penilaian } & \multicolumn{4}{|c|}{ Desa } \\
\hline & & & Lembar & $\begin{array}{l}\text { Jembatan } \\
\text { Kembar }\end{array}$ & $\begin{array}{l}\text { Lembar } \\
\text { Selatan }\end{array}$ & $\begin{array}{l}\text { Jembatan } \\
\text { Kembar } \\
\text { Timur }\end{array}$ \\
\hline 1. & $\begin{array}{l}\text { Kualitas jalan } \\
\text { a. Aspal } \\
\text { b. Pengerasan } \\
\text { c. Tanah }\end{array}$ & $\begin{array}{l}5 \\
3 \\
1\end{array}$ & 5 & 5 & 5 & 5 \\
\hline 2. & Sarana Angkutan & & 5 & 0 & 0 & 0 \\
\hline
\end{tabular}




\begin{tabular}{|c|c|c|c|c|c|c|}
\hline \multirow[b]{2}{*}{ No. } & \multirow[b]{2}{*}{ Variabel } & \multirow[b]{2}{*}{ Penilaian } & \multicolumn{4}{|c|}{ Desa } \\
\hline & & & Lembar & $\begin{array}{l}\text { Jembatan } \\
\text { Kembar }\end{array}$ & $\begin{array}{l}\text { Lembar } \\
\text { Selatan }\end{array}$ & $\begin{array}{l}\text { Jembatan } \\
\text { Kembar } \\
\text { Timur }\end{array}$ \\
\hline & $\begin{array}{l}\text { a. Terminal } \\
\text { b. Lainnya }\end{array}$ & $\begin{array}{l}5 \\
0\end{array}$ & & & & \\
\hline 3. & $\begin{array}{l}\text { Mode Angkutan } \\
\text { a. Kendaraan } \\
\text { bermotor/roda } 4 \\
\text { atau } 3 \\
\text { b. Sepeda motor } \\
\text { c. Delman/dokar/g } \\
\text { erobak/pedati } \\
\text { d. Lainnya }\end{array}$ & $\begin{array}{l}5 \\
3 \\
2 \\
1\end{array}$ & 5 & 5 & 5 & 5 \\
\hline 4. & $\begin{array}{l}\text { Jarak pusat } \\
\text { kecamatan dengan } \\
\text { kecamatan } \\
\text { terdekat } \\
\text { a. } \geq 25 \mathrm{~km} \\
\text { b. } 10-25 \mathrm{~km} \\
\text { c. } \leq 10 \mathrm{~km}\end{array}$ & $\begin{array}{l}1 \\
3 \\
5\end{array}$ & 5 & 5 & 5 & 5 \\
\hline \multicolumn{2}{|c|}{ Jumlah } & 20 & 20 & 15 & 15 & 15 \\
\hline \multicolumn{2}{|c|}{ Bobot (\%) } & 100 & 100 & 75 & 75 & 75 \\
\hline
\end{tabular}

Sumber: Hasil Analisis, 2017

Dari hasil pembobotan seluruh variabel penentu Desa Pusat Pertumbuhan di atas dapat diketahui bahwa Desa Jembatan Kembar merupakan pusat pertumbuhan (DPP) dalam Kawasan Pusat Pengembangan Desa (KTP2D) di Kecamatan Lembar. Adapun 3 desa lainnya seperti Lembar, Desa Lembar Selatan Desa Jembatan Kembar Timur merupakan sub

pusat atau daerah penyangga dalam KTP2D di kecamatan ini karena nilai bobot rata-rata dari tujuh variabel penentu DPP di desa-desa tersebut tidak mencapai 73. Untuk lebh jelasnya dapat dilihat pada Tabel 11

Pada Tabel 11 tersebut menunjukkan bahwa bobot yang diperoleh Desa Jembatan Kembar terhadap pembobotan 7 (tujuh) variabel penentu DPP adalah 73

Tabel 11 Bobot Desa Pusat Pertumbuhan (DPP) Kecamatan Lembar

\begin{tabular}{|c|c|c|c|c|c|}
\hline \multirow[b]{2}{*}{ No. } & \multirow[b]{2}{*}{ Variabel Penentu DPP } & \multicolumn{4}{|c|}{ Desa / Kelurahan } \\
\hline & & Lembar & $\begin{array}{l}\text { Jembatan } \\
\text { Kembar }\end{array}$ & $\begin{array}{l}\text { Lembar } \\
\text { Selatan }\end{array}$ & $\begin{array}{l}\text { Jembatan } \\
\text { Kembar } \\
\text { Timur }\end{array}$ \\
\hline 1. & Potensi Desa & 36 & 36 & 36 & 36 \\
\hline 2. & $\begin{array}{l}\text { Fasilitas untuk Menunjang } \\
\text { Perkembangan Produksi dan Jasa }\end{array}$ & 55 & 70 & 80 & 80 \\
\hline 3. & Kelembagaan Masyarakat & 50 & 50 & 50 & 50 \\
\hline 4. & Fasilitas untuk Pelayanan Jasa -Jasa & 53 & 53 & 53 & 42 \\
\hline 5. & Keadatan Penduduk & 100 & 100 & 100 & 100 \\
\hline 6. & Aksesibilitas & 100 & 75 & 75 & 75 \\
\hline 7. & $\begin{array}{l}\text { Gangguan Bencana Alam dan Penyakit } \\
\text { Menular }\end{array}$ & 100 & 100 & 100 & 100 \\
\hline \multicolumn{2}{|c|}{ Jumlah Bobot } & 494 & 509 & 494 & 483 \\
\hline \multicolumn{2}{|c|}{ Bobot Rata-Rata } & 71 & 73 & 71 & 69 \\
\hline \multicolumn{2}{|c|}{ Kategori } & DH & DPP & DH & DH \\
\hline
\end{tabular}

Sumber: Hasil Analisis, 2017 
Perlu pembangunan beberapa sarana untuk lebih meningkatkan fungsi Desa Jembatan Kembar sebagai pusat pertumbuhan bagi daerah - daerah hinterlandnya, yaitu:

1) Badan Usaha atau Perusahaan, badan usaha perlu diadakan agar dapat meningkatkan nilai jual produksi di sektor perkebunan dan peternakan.

2) Perlu diadakannya sarana persampahan, dan memperbaiki sistem pengolahan sampah yang ada untuk menciptakan kelestarian lingkungan di kecamatan ini.

Desa Jembatan Kembar sebagai pusat pertumbuhan dalam KTP2D di Kecamatan Lembar berfungsi sebagai penggerak perekonomian dalam kawasan ini bahkan penggerak perekonomian dalam ruang lingkup Lombok Barat, sebab seluruh pendistribusian barang yang berasal dari desa-desa hinterland ( Desa Lembar, Lembar Selatan dan Desa Jembatan Kembar Timur ) dan desa lainnya yang ada di Kabupaten Lombok Barat yang akan dipasarkan ke daerah lain seperti Kabupaten Lombok Tengah dan kabupaten lainnya akan melalui Desa Jembatan Kembar begitu pula sebaliknya pendistribusian barang dari Kabupaten lain yang akan masuk ke Kabupaten Lombok Barat akan melalui desa ini.

KESIMPULAN DAN SARAN

\section{Kesimpulan}

Berdasarkan hasil analisis dan pembahasan dalam menentukan Desa Pusat Pertumbuhan (DPP) di Kecamatan Lembar pada bab sebelumnya, maka kesimpulannya adalah sebagai berikut:

1. Sarana dan prasarana yang ada di Kecamatan Lembar secara umum sudah cukup tersedia dan sudah mendukung dalam pembentukan Desa Pusat Pertumbuhan.

2. Desa yang sesuai untuk dikembangkan sebagai Desa Pusat Pertumbuhan adalah Desa Jembatan Kembar karena bobot yang diperoleh dari 7 ( tujuh ) variabel penentu DPP, yang artinya Desa Jembatan Kembar. memiliki sarana dan prasarana serta memiliki potensi yang mendukung terbentuknya Desa Pusat Pertumbuhan di Kecamatan Lembar Kabupaten Lombok Barat.

\section{Saran}

Mengacu pada hasil analisis dan pembahasan pada bab sebelumnya serta mengacu pada kesimpulan di atas, maka dapat diajukan saran - saran yaitu perlu diadakan pembangunan beberapa sarana dan prasarana untuk lebih meningkatkan fungsi Desa Jembatan Kembar sebagai pusat pertumbuhan bagi daerah - daerah hinterlandnya seperti sarana komunikasi, pendidikan, serta pengadaan badan usaha atau perusahaan

\section{DAFTAR PUSTAKA}

Adisasmita R, 2006, Membangun Desa Partisipatif, Edisi Pertama, Graha Ilmu, Yogyakarta

Adisasmita R, 2008, Pengembangan Wilayah, Edisi Pertama, Graha Ilmu, Yogyakarta

Akbar M.I., 2010, Analisis Penentuan Desa Pusat Pertumbuhan (DPP) Kecamatan Rumbia Tengah Kabupaten Bombana, Skripsi tidak diterbitkan, Teknik Perencanaan Wilayah dan Kota, UIN Alauddin Makassar.

BPS, NTB, 2016. Provinsi Nusa Tenggara Barat Dalam Angka, Mataram, Tahun 2015.

BPS Lombok Barat 2016. Kabupaten Lombok Barat Dalam Angka, Gerung, 2016

Direktorat Pengembangan Permukiman, 2006, Panduan Praktis Identifikasi Lokasi KTP2D, Direktorat Jenderal Ciptakarya, Departemen Pekerjaan Umum, Jakarta

Rapermen, 2009, Pengalaman Empiris Penanganan Permukiman Perdesaan, http://rapermenbangkim.blogspot.com/2009/10/pengalaman-empiris.html (diakses 22 Juli 2013) 
34| Emi Salmah,Sahri,Endang Astuti/Analisis Penentuan Desa Pusat Pertumbuhan....

Rustiadi E. dan Dardak, E.E., 2008, Agropolitan: Strategi Pengembangan Pusat Pertumbuhan pada Kawasan Perdesaan, Edisi Pertama, Crestpent Press Bekerjasama dengan Direktorat Jenderal Penataan Ruang.

Sumpeno W., 2011, Perencanaan Desa Terpadu, Edisi Kedua, Reinforcement Action and Development (READ), Banda Aceh. 